\title{
RELEASE FROM KALA'S GRIP: RITUAL USES OF SHADOW PLAYS IN JAVA AND BALI
}

\author{
Ward Keeler
}

Comparative work in anthropology sometimes appears to be as perilous as it is unfashionable. That it is unfashionable is evident in the relative dearth of explicitly comparative studies published in anthropology over the past forty or so years. A few exceptions aside, the closest one usually comes is an edited volume in which each essay deals with a single society but an introductory essay by the editors hazards some broader comparative remarks. The reasons for such reticence seem clear: not only is it difficult for a single anthropologist to acquire enough expertise in more than one society to make comparative remarks with any authority, it also goes against the grain of much contemporary anthropology to try to make data from diverse societies fit the analytic categories-any analytic categoriesupon which comparison might be based.

This fear of reductionism, which defines the peril in comparative work, is well-founded: the disrepute into which so much earlier anthropology has fallen stems in large part from the brazenly reductive manner in which cross-cultural comparisons were made. Even comparativists as scrupulous and sophisticated as Boas and Lévi-Strauss still seem to lose too much of what matters about the societies they study when they embark on comparisons of ritual, myth, or social organization. Since many contemporary anthropologists wish to grant the objects of their study the dignity of subjects, they are particularly careful to avoid fitting their data into preconceived molds. Of course, it is a truism that anthropology always presumes an implicit or explicit comparison with the society of the analyst, and that the description of "them" always consists in large part of a negative image of "us." Most anthropologists try to overcome the distortion that that inevitable comparative perspective implies by building as thorough and complex an image of another society as possible. To do the opposite, to make comparison central to their endeavor, would appear to many to be quite retrograde.

Yet there is a certain cost to avoiding the reductionist dangers of comparative work: it tends to make all the "not-us" peoples in the world begin to look alike. If, for example, the West is uniquely preoccupied with the status of the individual, then all societies that differ 
from us by a greater emphasis on groups will appear in Westerners' descriptions to resemble each other. Only when one "them" is compared explicitly to another "them" will their shared differences from us begin to lose their prominence in our understandings and a different set of affinities and contrasts begin to stand out. Such a triangulating process should sensitize us to important characteristics of the societies explicitly compared, and enrich our self-understanding as well.

In an effort to pursue such a goal, on however modest a scale, I have embarked on a study of certain Indonesian stories. These stories are found in two closely related societies, namely, Java and Bali, are clearly cognate with one another, and provide the basis in each society for a ritual use of shadow plays. The question I wish to address is this: if we believe, as I think we must, that there exists some connection between the stories people tell, the rituals people practice, and other things people in a particular society do, then it seems reasonable to assume that differences one finds in the stories and practiced in two societies will correspond in some way to other sociological and cultural differences between them. Furthermore, if two societies are clearly related historically, linguistically, and culturally, then their stories and rituals should show some variation, and some consistencies, that are susceptible of closer analysis than comparison of two very distant societies would allow.

However reasonable the above propositions may appear, they are obviously tendentious. The nature of the relations between stories, rituals, and the societies in which they are found is not at all certain. In fact, if anything seems clear, it is that there is no single type of connection, whether psychological, sociological, or whatever. But the fact that there is no essential relationship should not dissuade us from looking at what goes on among the people that tell stories and/or practice rituals, in order to see whether doing so will help us understand what resonance those stories and rituals might have for the people that tell, hear, do, and/or know them.

But how is analysis to proceed comparatively? If one abandons faith in the coherence of societies as organic wholes, it is hard to see how to compare one society with another in any overarching way. If, in addition, myths and rituals do not enter into systematic relations with those societies no longer conceived of as necessarily integral or coherent, then it may seem pointless even to try.

Lévi-Strauss, in his Mythologiques, ${ }^{1}$ is little daunted by such concerns, and he puts specific contexts aside quite readily in his pursuit of the inherent structures of the human mind. That solves the problem of cross-cultural comparison rather neatly-since minds are universal, logical structures can be discerned across cultures without worry-but it entails sacrificing attention to what place myths might have in a particular society. The comparative work of Dumézil and other Indo-Europeanists is grounded rather more closely in specific societies and their history, but it also works at quite a high level of abstraction, removed from anything like ethnography. Southeast Asia would certainly prove fertile ground for a Dumézilian comparative mythology, but studies that stick closer to the lived reality of particular societies are also needed.

Greg Urban, a linguistic anthropologist of unusually wide-ranging interests, looks in a recent book at the relations between societies and their myths in a rather different compara-

${ }^{1}$ Claude Lévi-Strauss, Mythologiques, Vol. 1-4 , tr. John and Doreen Weightman (Chicago: University of Chicago Press, 1990). 
tive manner. ${ }^{2}$ He suggests that examining the particular telling of myths can reveal much about the culturally specific meanings myths have, even when, as often occurs among Native Americans of both continents, many elements of the myths recur in diverse societies. In looking at the Indonesian stories that follow, I have drawn on Urban particularly for his stress on specific discursive forms, because a concern with unusual forms of discourse runs through all the stories I wish to examine.

However, I also wish to connect elements in the myths to the everyday experience and social relations of people in Java and Bali. I should stress that my comments are not intended to describe Javanese or Balinese societies as single, monolithic wholes: we all know that such approaches have been discredited. The generalizations I make are intended simply as indications of behavioral patterns and ideas, expressed either explicitly or implicitly by some Javanese and/or Balinese, that give social relations and individuals' comments about those relations a certain degree of consistency. The "meanings" I see in the stories and rituals are not normative rules or inviolate truths. Rather than speak of meanings inhering in the stories at all, I would suggest that the stories treat issues of concern to many Balinese and Javanese, but give systematic, uncontested, or conclusive expression to neither those issues nor any possible solutions.

I approach the comparison of the stories and associated rituals first by considering where the differences between them lie, then by considering where the different versions converge. My contention is that elements that differ can be linked to contrasting sociological arrangments in Java and Bali, and/or to different cultural emphases in the two societies more generally. Java has cognatic kinship and there is a great emphasis on personal autonomy, whereas Bali has patrilineal kinship and there is a great emphasis on exchange relations, both among individual and group elements in the stories, and the associated ritual performances in the two societies vary in accordance with those differences. The stories' and rituals' similarities, meanwhile, which I consider next, stem from fundamental issues that preoccupy people in Java and Bali alike, issues particularly that concern language and power. The similarity that intrigues me most is the use of shadow plays to achieve the essential ritual ends in both the Javanese ruwatan and Balinese penglukatan, as the ritual shadow plays are named. I examine what it is about shadow plays that makes them seem so germane to these rituals for both Javanese and Balinese, and I conclude by suggesting how these stories/rituals/performances help us to understand the great appeal of performing arts of all sorts in Java and Bali.

\section{The Stories}

Readers of James Boon's Other Tribes, Other Scribes will recall the story of "Lady Uma and the Cowherd" that he analyzes in his sixth chapter, "Balinese incest recaptured: a discourse." 3 That story is derived from the fifteenth-century text, Tantu Panggelaran, written in Old Javanese and translated into Dutch by Pigeaud. ${ }^{4}$ In Bali the story is often linked, in one

\footnotetext{
2 Greg Urban, A Discourse-Centered Approach to Culture: Native South American Myths and Rituals (Austin, Tx.: University of Texas Press, 1991).

3 James Boon, Other Tribes, Other Scribes (Cambridge: Cambridge University Press, 1982), pp. 178-206, especially $181-88$.

${ }^{4}$ Th. G. T. Pigeaud, De Tantu Panggelaran: een Oud-Javaansch Prozageschrift (The Hague: Smits, 1924). See also Jacoba Hooykaas, "The Myth of the Young Cowherd and the Little Girl,"Bijdragen tot de Taal-, Land-en Volkenkunde (hereafter BKI) 117, 2 (1961): 267-81 for a brief summary and analysis in English.
} 
form or another, to another story, called "Sapu Lègèr." Several elements of "Sapu Lègèr," in turn, recall an important Javanese story, called "Murwakala." Each of these stories is interesting in itself. But what makes them still more interesting is that all are implicated to one degree or another in ritual uses of shadow plays, and both "Murwakala" and "Sapu Lègèr" include in their story lines the performing of shadow plays. So, too, does a Balinese followup to "Lady Uma and the Cowherd." Indeed, the number of correspondences among the stories and rituals demonstrates that they are cultural cognates of one another.

\section{A. "Murwakala"}

The following summary is based upon a performance of "Murwakala" held as part of a ruwatan for five brothers who lived with their parents in a village near Klaten, Central Java, in 1978. A ruwatan is held in order to fend off the danger that threatens certain categories of people, such as single children, two children of opposite gender, or as here, five children of the same sex, who are said to be the rightful prey of a monster named Bathara Kala. ${ }^{5}$

When a monster forces his way into heaven, Lord Guru is reminded by his prime minister, Narada, that the monster is Guru's own offspring. Not long before, as Guru and his queen, Uma, rode about the heavens on the back of the bull Andhini, the rays of the rising sun made Uma appear especially beautiful. Uma rejected Guru's amorous advances, but Guru was unable to restrain his desire, and his semen fell to the sea below. Despite the gods' efforts to disperse the semen, it took on the form of a monster and made its way to heaven. Guru, having first wished to ignore the child, now gives him a name, Kala. He also gives him clothes, a wife, Durga, an army, and a weapon, plus a list of certain types of humans, who are defined as polluted (sukerta), and whom Kala can eat. Finally, Guru pronounces magical formulas that are inscribed on Kala's body. Kala must recognize any human who can read these formulas as his father and submit to him. Kala then departs. At noon, Guru and Uma, riding on Andhini, come upon Kala sleeping and wake him. Kala points out that, because they have been out and abroad at noon, they are his rightful prey and he intends to eat them. Guru poses riddles for Kala, however, as a condition to his devouring them. When Kala answers correctly, Guru points out that since it is no longer noon, Kala must give up his claims to the right to eat them. Kala then pursues the five sons of Bapak Suharjo and his wife, who live in Karangwétan. [These were the names of the sponsors of the performance and the village where the performance was being held.] Bapak Suharjo and his sons flee to the village of Purwacarita. Kala is obstructed in his chase by a number of obstacles, such as a length of bamboo in which the dividers between sections have been removed but the bamboo left lying about the yard. In each case, Kala curses the person whose negligence has prevented him from catching his prey. In heaven, Guru instructs two of his sons, Wisnu and Brama, to take on the form of a shadow puppeteer (dalang), ${ }^{6} \mathrm{Ki}$ Kandhabuwana, and his assistant, the player of a musical instrument (the gendèr), and go to earth to protect humans from Kala's attacks. The scene shifts to the village of Medhang Kamulyan, where the headman tries to persuade his daughter that she should stick with her new husband, despite her antipathy for the married state. She finally agrees but on the condition that her father hold a shadow play (wayang) for her at the time of the ceremony marking the thirty-fifth day of a marriage. Wisnu performs as dalang, to the delight of a great crowd. In his pursuit of

\footnotetext{
${ }^{5}$ The list of people who fall into this category is actually very long and includes people who have committed some misstep, such as breaking a grinding stone, as well as people born into a family in which the constellation of siblings is inauspicious. But it is almost exclusively the latter type of cases that impels people to carry out a ruwatan.

${ }^{6}$ In Java the word is spelled dhalang, but 1 have used the Balinese spelling of dalang throughout this article.
} 
Suharjo and his five sons, Kala happens on the scene and is so entranced by the puppeteer's performance that he stays to watch, and becomes drowsy. But at dawn he is disappointed that the performance is over so soon. He urges the puppeteer to continue. Kandhabuwana agrees to do so if Kala will give him his weapon in exchange. Kala agrees, and Kandhabuwana begins to perform "Murwakala," recounting the origin of Kala. Thieves, caught in the act of breaking into someone's home, come running to the performance area and hide among the gamelan players. Attracted by the performance, a baby's parents have left it unattended. Kala grabs the child and signals to the puppeteer to stop. He wants to regain possession of his weapon long enough to kill the baby. Just then Bapak Suharjo enters. Suharjo asks the puppeteer to protect his sons from Kala. Kandhabuwana makes a deal with Kala: he will return the weapon to Kala, so that in future Kala can obtain food, but Kala must give up the baby and the five youths and so go without eating today. Kala agrees, and he entrusts the baby to the puppeteer as an anak sampir (anak: child; sampir: tag along). They then argue over who is more senior, Kandhabuwana or Kala. Kandhabuwana knows Kala's origins, however, and can read the writing on Kala's body. So Kala is convinced of Kandhabuwana's seniority. But he wishes to know how the puppeteer will perform the rite, ridding the five sons of their defilement.

[At this point the dalang who was giving the performance announced that he was about to start reading the serat pengruwatan (serat: letter, text; pengruwatan: purification). He advised pregnant women to move beyond earshot, and adults to wake any children sleeping in the area. The loudspeaker was disconnected, the five young men for whom the rite was being performed were told to lean their heads against the banana tree trunk at the base of the screen, incense was burned near the screen, and the gamelan orchestra began to play. The musicians told me to turn off my tape recorder. The dalang took the text, handwritten (in Javanese script) on paper, out of the cloth wrapper in which it was stored, rested it on a pillow, and began to read in a sing-song chant. The reading lasted about twenty minutes, the dalang selecting passages out of a longer text. At the end of the reading, most of which was unintelligible to the spectators, the puppeteer cut a lock of each young man's hair. The performance then resumed.]

Kala avers his submission to Kandhabuwana, whom he acknowledges as his father. He has become completely limp and powerless because of the reading. The puppeteer returns Kala's strength to him, but on the condition that he leave Karangwétan and never bother Bapak Suharjo's family again. Kala leaves. The thieves come forward. They agree never to rob anyone in the village, and they promise that neither they nor any of their descendants will rob the puppeteer or any of his descendants. A series of spirits then come forward to ask Kandhabuwana for some portion of the many ritual goods and materials the sponsors have assembled for the ritual. These belong by rights to the puppeteer at performance's end, but he is willing to award the spirits these boons in return for their assistance to the villagers, or at least their departure from the area. He responds to each request by saying, "Take them if you find what you request. If not, may you grant forgiveness." [He answers in this way because it is the sponsors' responsibility, not his, to ready these things for the rite.] Finally, the two gods, Wisnu and Brama, return to heaven, leaving behind the human aspects of the figures they have taken on.

\section{B. "Sapu Lègèr"}

In his book on Balinese wayang, C. Hooykaas provides several variants of the "Sapu Lègèr" story. One, in verse form, appears in a chapter Hooykaas entitles "The Kidung 
Sapu(h) Leger (K. 645),"7 with the note, "The Kirtya collected this poem in Singaraja in the early thirties." 8 It is in literary but quite accessible Balinese. The story can be summarized as follows:

Guru has two sons, both born on Saturday in the week $(u k u)$ called wayang (one out of the thirty named weeks in the $u k u$ cycle). The older, Kala, is of demonic appearance, the younger, Raré Pañca Kumara, handsome. Kala is furious that his younger brother has the same oton as his own (that is, that he and his brother were born on the same day of the week in the same $u k u$ ), and asks of his father, Guru, permission to devour his younger sibling. Guru tells Kala to wait seven years. Sorrowfully, Guru summons Kumara and tells him of Kala's intention, from which he has been unable to dissuade Kala. Then Guru lights on the idea of cursing Kumara to permanent childhood, never to grow up. Nevertheless, after seven years, Kala returns, still intent on devouring Kumara. Guru persuades him to wait another three years, that the boy may grow bigger, and when that time elapses, yet another three days. Disappointed that Kumara remains small, Kala nonetheless decides he will wait no longer. Guru advises Kumara to seek refuge in the kingdom of Kertanagara. Kala soon sets off in pursuit of him. Kumara escapes by a series of ruses: hiding in a sheaf of reeds, hiding in a bundle of firewood left untied, escaping through an oven's smoke vent. Each time that Kala is foiled in his pursuit of Kumara, he curses the person whose work, or carelessness, has enabled Kumara to get away. In Kertanagara, the king has learned of Kumara's flight from Kala and is prepared to defend him. But his army and the king himself are destroyed by Kala, who then continues in his pursuit of Kumara. He succeeds in swallowing Kumara, but Guru forces him to spit him out, which Kala does despite himself. The chase continues. Kala comes upon Guru and his queen, Uma, riding on Guru's white bull at noon. Kala is about to devour them when Guru puts as a condition that Kala solve a riddle he recites. Kala is unable to solve it, and Guru points out that the sun has now descended in the sky. Since it is no longer noon, Kala is deprived of the right to devour his parents. Kala curses the coconut palm always to be crooked, because it had not obscured the sun. He continues in his chase. At night, Kumara happens on a performance of a shadow play being given in the week ( $u k u$ ) named wayang. He begs the puppeteer to protect him. The dalang tells him to hide in the gendèr. Kala arrives and cannot restrain himself from eating the offerings assembled for the performance. The dalang urges Kala to take the offerings in place of the children, born in the week of wayang, he pursues. Kala pronounces a magic formula granting the dalang the ability to free all living things from evil, and then withdraws. Kumara is taken up to heaven by Guru and Uma.

\section{C. "Lady Uma and the Cowherd" and "Sapu Lègèr"}

In the chapter following the above, Hooykaas provides another "Kidung Sang Empu Lègèr." 9 This one, which I summarize below, includes the story of "Lady Uma and the Cowherd" at the outset.

Lady Uma, seeing her husband sick, follows his instructions to go to find milk of a cow as medicine for him. Guru himself then takes the form of a cowherd who is old but still sexually inexperienced. He is willing to trade the milk Uma requests of him only in return

${ }^{7}$ Christian Hooykaas, Kama and Kala: Materials for the Study of Shadow Theatre in Bali, Verhandelingen der Koninklijke Nederlandse Academie van Wetenschapen, afd. Letterkunde, Nieuwe Reeks, 79 (Amsterdam, NorthHolland, 1973), pp. 220-43.

8 Ibid., p. 220.

${ }^{9}$ Ibid., pp. 244-66. 
for sexual intercourse with Uma. Lady Uma, full of consternation, finally accedes to his desires, but moves her vulva to her thigh in view of the cowherd's lowly station. On returning to Guru, Uma is questioned as to how she obtained the milk. Their son, Gana, is asked to consult the book in which all knowledge is contained. Gana's revelation of her infidelity enrages Uma, who becomes a monster, Durga, and burns the writing. Gana gathers up the leaves and restores the book, but his younger brother Kumara appears and scatters them, destroying forever the possibility of perfect foresight and knowledge. Gana wishes to kill Kumara, but Guru persuades him to wait until the boy is older. Guru then vows that Kumara will remain a child forever and the protector of babies. Uma is pregnant and eventually gives birth to an egg resembling a cooking pot. The gods' efforts to destroy it prove fruitless. Instead, Kala appears, demanding food. Once Kala has wreaked havoc in heaven, Guru sends him to earth to seek further prey, and then limits his victims to only certain types of people. Kala is ravenous but humans are being decimated. Guru and Uma, riding on the back of white bull, come upon Kala at noon. Kala is delighted at the opportunity to eat them, but fails to solve the riddle Guru puts to him and the sun moves beyond its zenith. Guru grants Kala the right to eat people born in the $\bar{u} k u$ wayang, and Kala resumes his search for food. A brahman has two children, Raré Brata and Raré Brati, both born in $u k u$ wayang. He tells them they must flee. Brata escapes Kala by means of a series of ruses, each of which incurs Kala's wrath and causes him to curse the object that enabled Brata to elude Kala. Guru becomes a dalang on earth and a performance area is set up, replete with offerings. The dalang performs the story of Kala's search for food. Raré Brata comes upon the scene, Kala just behind him. Kala is surprised to find himself appearing in the play. He eats the offerings, leading to a confrontation with the dalang. Kala is awed by the dalang's knowledge, and agrees to take the offerings in place of people born in the $u k u$ wayang. Brata is purified, Guru takes on his usual form and instructs Kala to eat only offerings, not human victims, and to leave the world for the Void.

I collected from a dalang in eastern Bali an extension of the story concerning Guru and Uma, which I summarize below.

Uma leaves in a huff when her infidelity has been revealed and she has taken on the form of a monster resident at the Pura Dalem. However, Siva [more commonly referred to in Bali as Guru] eventually longs for her, and wishes to meet with her [the verb, mapanggih, can mean "meet with" or "have sexual intercourse with"]. So he takes on the form of a monster, too, and joins her at the Pura Dalem. The son of Wisnu, Takipati, who is the king of Medangkamulan, realizes that something must be done: the world has become chaotic due to Siva and Uma's departure from heaven. He summons Brahma and Iswara to earth, and enlists their aid. They decide to put on a wayang in the Balé Agung. They do so, Iswara as the dalang and Wisnu and Brahma as his assistants, and in their performance they depict

Siva's deeds and their consequences. Reminded in this way, Siva decides to return to heaven, and lifts the curse on both himself and Uma.

\section{Divergences}

\section{Fathers and Brothers}

An important difference between the Javanese and Balinese stories is that "Murwakala" emphasizes tensions between paternal figures and their real or fictive children, whereas "Sapu Lègèr," while it concerns such intergenerational tensions, focuses more centrally on tensions between brothers. 
I believe sociological differences between Java and Bali make sense of this difference in emphasis. A society like Bali that is primarily patrilineal and virilocal is likely to find conflict among brothers (and cousins) both frequent and problematic, more so than a society, like Java, that is more thoroughly cognatic. In principle, older brothers are entitled to higher status than younger ones in both societies. In both Java and Bali, for example, younger brothers address older ones with kinship terms rather than their names, while older brothers address younger ones by name (or sometimes birth order name, in Bali). Older brothers are enjoined to protect and support their younger siblings, in return for the latters' acknowledgement of their superior status. In practice, however, things tend to work out rather differently in the two societies.

In Java the most common relationship among brothers is a more or less polite distance. During my first stay in Java, in a village outside Yogya, I was startled to learn several months after I had started boarding with a family that a man I saw only very occasionally in the house was an older son living in the same hamlet. Avoidance relations among all males even within a household are often quite marked, ${ }^{10}$ and by the time of marriage brothers live not only in separate houses but, given the preference for either neolocal or uxorilocal residence, often in different hamlets as well. Certainly, Javanese brothers and cousins fight. Disputes over inheritance in Java are probably the most common form of fraternal strife, but life in Java presents many opportunities for brothers to come into conflict. Yet the physical and emotional distance that is likely to take hold as brothers grow up, as well as the customarily equal division of inherited property among males (and often females) on or even before their parents' deaths, makes the actual ordering of status among brothers relatively unproblematic.

In Bali, the potential for dispute is greater. Division of property is not always equal, and much more in the way of titles and offices is likely to be at issue than in Java. ${ }^{11}$ James Boon has shown that the ideological preference for primogeniture among gentry in Bali, a rule that should ostensibly maintain some order in the process, is frequently contradicted in practice, ${ }^{12}$ a point Hildred Geertz and Clifford Geertz also make. ${ }^{13}$ The fluidity of the system only fosters competition and tension. Nevertheless, brothers should ideally remain in the same or a nearby compound, along with patrilineal cousins. They may very well not do so, but when this is the case there is likely to be a story behind it. At least, such was the case until recently, when it became common for many young people to leave villages for residence in town, thereby obviating in many instances the issue of fraternal conflict.

In a society predicated on hierarchical difference, to resemble someone of higher status, whether intentionally or not, is inadmissible. It is also intrinsically dangerous for all parties, because it challenges the effectiveness of hierarchy in ordering social relations. Brothers, however, risk doing just that: except for birth order, sociologically they are very much alike, and the problem about brothers in both Java and Bali is that, unlike parents and children, the differences between them are not really all that great. So they pose something of a challenge to social order, and to each other, especially when, as in Bali, brothers compete among themselves for their patrimony and yet are expected to address the rest of the world at least to some degree in concert.

\footnotetext{
${ }^{10}$ Hildred Geertz, The Javanese Family (New York: Free Press of Glencoe, 1961), pp. 121-22.

${ }^{11}$ Hildred Geertz and Clifford Geertz, Kinship in Bali (Chicago: University of Chicago Press, 1975), pp. 53-54, $140-43$.

12 James Boon, The Anthropological Romance of Bali (Cambridge: Cambridge University Press, 1977), p. 71.

${ }^{13}$ Geertz and Geertz, Kinship in Bali, p. 54.
} 
It may seem unnecessarily deterministic to tie the emphasis in "Sapu Lègèr" on fraternal strife to Balinese kinship and residence patterns. Yet to forgo sociological data in seeking explanations for what happens in stories strikes me as a kind of intellectual sequestration, avoiding the contamination of functionalist explanations but at the cost of ignoring some important evidence.

\section{Autonomy vs. Exchange}

A second area in which the stories and the attendant rituals differ is the means by which Kala is overpowered. In both the Javanese and Balinese stories the dalang is the figure capable of protecting Kala's victims and of sending Kala packing. In both, the dalang does this first by making a display of his power and then by negotiating an agreement with Kala. However, the essential gesture in the Javanese version consists of reading the writing on Kala's body, whereas in Bali it consists of making the appropriate offerings and obliging Kala to accept them.

The difference between writing and offerings is crucial, as it implies exchange and so interdependence, on the one hand, and their denial, in autonomy and the possibility of unilateral action, on the other. These issues are fundamental in all these stories and rites, as elements of exchange relations, their permutations, and their perversion, are implicit in "Murwakala," "Lady Uma and the Cowherd," and "Sapu Lègèr."

Exchange relations constitute one form of interdependence: they imply that each party to an exchange is either in need of or at least desirous of what the other can provide. The obverse of exchange is a unilateral exercise of power. But exchange and unilateral action receive differing weight in these stories. Writing vs. offerings, as will be discussed below, exemplifies that contrast in emphasis, because writing, particularly as it is represented in the Javanese ritual, is an expression of autonomy, whereas offerings, as emphasized in the Balinese one, denote exchange. This difference in emphasis fits a more general difference in Balinese and Javanese attitudes toward social relations: interdependence, as instanced in relations of collaboration and exchange, is presumed by Balinese to constitute the primary means of making one's way in the world, while Javanese, in contrast, are inclined to look upon it as a necessary yet still compromising element in most people's lives.

Asceticism and writing in the Javanese ruwatan. In an earlier analysis of "Murwakala" and a number of other Javanese stories, ${ }^{14}$ I suggested that Javanese tend to contrast exchange and autonomy, favoring the latter as indicative of superior power and status and associating it more readily with males than females. The optimal means to power, in the ideology of Javanese lowlanders, is to engage in ascetic exercises, such as fasting, giving up sex, going without sleep, etc. These practices suggest a person's ability to withdraw from all interaction, in a denial of all relations with the world.

Sexual relations are a particularly powerful instance of interdependence. Javanese do not promote celibacy as a good in itself. Only in circumstances in which they stand most in need of marshaling their strength are males enjoined to refrain from sexual intercoursesuch as when a dalang is preparing to carry out a ruwatan. ${ }^{15}$ However, Javanese men do

\footnotetext{
14 Ward Keeler, "Javanese Generations: Gender Roles and Intergenerational Ties in Java." Paper prepared for the SSRC Conference on The Construction of Gender in Island Southeast Asia, organized by Shelly Errington and Jane Atkinson, Princeton, N.J., 1983.

15 Prohibitions on sexual intercourse apply to women much more than men. A nursing woman should not engage in sexual activity for fear of spoiling her milk, and Javanese generally believe a child should nurse for
} 
express suspicion of the emotional investments that sexual attachments, or any feelings for family or kindred, might entail. That is, to have sex is not necessarily compromising to a man, unless he is attempting to pursue a specific ascetic course. But to become infatuated is compromising, and so even is becoming immoderately devoted to one's family. A dalang who lived eighteen years apart from his wife and family boasted of that fact in conversation with me. He had gone off "to the forest" in pursuit of his own and his family's welfare, rather than simply fulfilling the emotional wants of his wife and children. Autonomous action on his part, he appeared to feel, fulfilled the obligations he had toward his family better than everyday interaction at home would have done. This is an extreme case, not one typical of Javanese family life. Yet it indicates an ideological tendency in Java, particularly widespread among males, that places the ascetic path of autonomy above the interdependent one of everyday social intercourse.

The ultimate ascetic rigor people speak of in Java is to spend forty days fasting in a cave or other potent, that is, mysterious, impressive, or scary, space. This total isolation-the perfect image of autonomy-is thought greatly to increase an individual's ability to control other people and events on returning to the world. In particular, one becomes capable of using potent speech, language that is not simply meaningful but rather effective (mandi, a word also applied to poison and medicine), achieving the ends or conditions it names. At the same time, one becomes impervious to others, unaffected by their speech or any mystical attacks they might attempt against one.

Becoming truly powerful is an ideal most people can only admire in others, such as the Sultan of Yogyakarta or President Suharto. They rarely expect to attain much potency themselves. Nevertheless, many people in the Principalities undertake modest rigors, such as eating no salt on Monday and Thursday, as minor steps toward better fortune. ${ }^{16}$ In subscribing to these notions about ascetic exercise, people buy into a conception of social relations that idealizes autonomy and disvalues interdependence, however much their practice contradicts that ideological commitment.

A dalang who gives a ruwatan is enjoined to carry out some ascetic exercises before performing the ritual. He denies commerce with the world in another way, as well. Even though a dalang is of course paid for giving a ruwatan, and quite handsomely, he is invariably at pains to deny his interest in payment. This self-presentation speaks for a lack of investments in worldly wealth, a trait assumed, at least ideally, to characterize powerful people in Java. This same message is expressed in the ruwatan, in the series of encounters at its conclusion, when a number of characters come forward and ask the dalang for some of the offerings assembled near and on the screen. The dalang says these suppliants are welcome to take whatever they have requested if the offerings they seek are indeed to be found there. ${ }^{17}$

two years or so. During this time of a woman's abstinence, however, many men feel it is within their rights to sleep with prostitutes if they feel so inclined.

${ }^{16}$ I have used gender-neutral language in the preceding paragraph because Javanese speak of asceticism as something both men and women may practice. Nevertheless, men are usually thought both more inclined to undertake ascetic exercises than women and more adept at doing so. When women do engage in such practices, as Suzanne Brenner has pointed out to me, then the aims they strive for tend toward increasing the good fortune and status of their families, rather than achieving more individual goals. I have spoken of people in the Principalities because I encountered comments on asceticism much more frequently there than in the area of Salatiga, where I have done fieldwork more recently.

${ }^{17}$ An elderly dalang, a relative of the family I stayed with during my fieldwork, had married a second time to a younger woman much despised for her rapacity. After some of the dalang's nephews played in the orchestra for a ruwatan he gave, they reported to their parents in hilarity and contempt that the old man's wife started packing 
In sum, a dalang who performs a ruwatan must be seen to fulfill the ideal of a potent, autonomous individual. By this means, he resembles Guru, and an important motif in both "Murwakala" and "Sapu Lègèr" is the dalang's role as the god's double. In "Murwakala," Guru demonstrates, however inadvertently, his own ability to act independently, when his semen proves generative on its own. The dalang's purpose is to undo what Guru has accomplished. But he does this through the writing that Guru has inscribed on Kala's body, activating it and thereby replicating Guru's own authority.

The place of writing in controlling Kala must hinge on the fact that writing is a unilateral but effective use of language, one that is analogous to Guru's unilateral but productive ejaculation of semen. The dalang might be said-though the association is mine, not that of anyone I spoke to in Java- to take on the characteristics of writing itself.

Writing differs from most speech inasmuch as speech implies an ongoing exchange, the give and take of discourse in everyday forms, whereas writing occurs outside such specific contexts of exchange. Among forms of speech, only potent speech, the speech of the truly powerful, escapes the implication of exchange relations in this way, since potent speech imposes itself on the world. Writing is analogous to such speech in that it is conceived of as permanent, inviolate, and unchallengeable. True, writing depends for its realization on a reader. Writing may, furthermore, be ignored. But its status in a society like Java, where until recently only the privileged few were literate, has given it a special authority that makes it harder to ignore or belittle than is the case in a more writing-saturated society. What gives it a special status for many Javanese is that it exists on its own, detached from any source, and is therefore a kind of autonomous language.

Javanese dalang certainly consider the serat pengruwatan, the written text they read in performance, extremely powerful. Making a copy of one is surrounded with ascetic requirements and ritual precautions, and dalang are forbidden to read the text except on the occasion of a ruwatan. At a performance, when the reading is about to start, warnings that sleeping children should be awakened and pregnant women should leave the scene emphasize that power is about to be unleashed. But only a powerful individual is capable of realizing the power that inheres in the written text.

To detonate power suggests a radical distinction between the power holder and the object over whom power is wielded. In "Murwakala," reading the writing is intended to affirm such a distinction between, on the one hand, Guru and the dalang as his representative, and, on the other, Kala. The writing Guru inscribes on Kala's body makes Kala permanently vulnerable to the authority of any person who can read that writing. Such a person must be "recognized as father" (diaku bapa) by Kala. So whenever the writing on Kala's body can be reactivated by becoming the potent speech of a powerful person, then the relationship between Kala and Guru is reestablished. But that relationship is not marked by any sense of their mutual interdependence, whether affective or political or whatever, but rather by Guru's power, his son's submission, and their disjunction. Such a relationship is aptly represented in writing, because writing is predicated upon the disjunction between writer and reader and/or whatever is subject to the writing's power.

up the offerings before the performance had even ended, and that she and her husband could be seen speeding away in a buggy within minutes after the final gong. "She was afraid someone would ask for some of the offerings," their mother said disdainfully, noting that in life people ask the puppeteer for a share of them as boons, just as characters do in the story. 
Paternal authority is idealized as both beneficent and incontrovertible in Java, and the dalang is represented as exercising such authority over both Kala and the person(s) in need of the ritual, the anak ruwatan. (For the rest of their lives, anak ruwatan are supposed to inform the dalang of any life-passage ritual they undergo. The same is true of any child born in the neighborhood where a dalang is performing [anak sampir].) A dalang can take on this role as, in effect, a stand-in for Bathara Guru himself, as well as father of the anak ruwatan and anak sampir, only if he has gathered enough power of his own to enable him to control the power that inheres within the writing. Once again, he can attain this power, in the view of most dalang, by means of ascetic exercises. So the power of the dalang, as gained through the radically autonomous action of ascetic exercise, enables him to unleash the power that inheres in what might be called the unilateral language of writing. The dalang's reading is not a communicative act but rather an assertive, effective one, not an exchange of language as in everyday speech, but an autonomous action.

Interdependence of any sort-sexual, affective, political, and/or commercial—carries with it the implication that each party to the relationship enjoys some leverage over the other. There may be a great disparity in status and authority, but neither party is absolutely powerful, since each stands in some need of or desire for what the other can provide. Exchange relations make this interdependence clear: monetary, linguistic, and labor "exchanges" imply voluntary participation on the part of two or more parties. Our terms "sexual commerce" and "intercourse" suggest that sexual relations may be thought of as a kind of exchange, as well. Of course, some exchanges are forced, and indeed Kala agrees to enter into exchange relations with the dalang only under some duress. But interdependence and exchange still imply some room for negotiation, whereas unilateral action implies its irrelevance. In "Murwakala" and the ruwatan, exchanges certainly take place. But it is the possibility of escaping them, and all forms of interdependence, that seems to motivate much of what happens, in both the story and the ritual. Guru's semen and his writing, and the dalang's ascetic exercises and his reading, all provide images of autonomy and independence.

Offerings and interdependence in the Balinese penglukatan. In contrast to my experience in Java, where people in villages in the Principalities spoke at great length of the benefits of ascetic exercises, I was struck in Bali by how little attention people paid to such notions. The procedure by which individuals acquire greater religious authority, mawinten, does involve some forms of ascetic rigors. But there was no sense among villagers I knew near Tabanan that undertaking ascetic practices on an everyday basis would bring them benefits either material or spiritual. Instead, emphasis fell entirely on fulfilling ritual obligations, and, above all, on making appropriate and abundant offerings to gods, ancestral spirits, and territorial spirits, that is, on maintaining proper exchange relations with them.

Overall, interdependence in social life, particularly in the form of exchange, receives much greater emphasis in Balinese society than in Javanese. Interdependence in Bali does not appear to be an unfortunate, if necessary, means by which humans make do in this world, as it appears to many Javanese. In sustaining judicious relations with the unseen beings that crowd the Balinese physical and social landscape, entering into exchange is simply common sense. The penglukatan is conceived of as the occasion in which a great array of offerings are made to Kala. By this means, he is drawn into a relationship of exchange that resembles most Balinese relations with supernatural beings: offerings (banten) are offered in return for gods' or spirits' benevolent influence, or at least, and probably more often, their benign neglect. 
In sustaining relations with other humans, of course, the issue of exchange is somewhat more complicated. The famous institution of the Balinese sekaa is an enabling device for labor exchanges without parallel in Java. At the same time, caste distinctions in Bali give rise to some measure of interdependence among members of different groups, not of course to the degree Dumont claims for India, ${ }^{18}$ but both ideally and really nonetheless. Balinese social life seems based on an explicit recognition of how much interdependence matters.

Kinship might appear to provide a counter-example. To the extent that endogamy is the most prestigious form of marriage in Bali, then minimizing exchange by drawing it in to the narrowest degree is the preferred option, thereby avoiding any suggestion that one's kin group is dependent on, or subordinate to, others. At the top of the status hierarchy, as Boon demonstrates, ${ }^{19}$ whether in the case of gods-in incest-or of humans-in patriparallel cousin marriage-this option is pursued most fervently. Yet Boon has also shown that no single form of marriage exchange really predominates in Bali: every marriage must be considered in the larger context of other marriages, and of any one patriline's circumstances and goals. So at the top of the status hierarchy (or hierarchies), Balinese and Javanese understandings of the link between high status and relative autonomy resemble each other most closely. That is, the way to maintain or maximize high status in either society consists in minimizing intercourse with outsiders. Yet it is noteworthy that, even when Balinese engage in endogamy, they still effect an exchange: a marriage still takes place. In Java, the idealized image of the isolated ascetic denies the significance even of sexuality and generation, putting the issue of strategic alliance aside.

Balinese thus approach relations with gods, ancestral spirits, demons, and each other with some assurance that exchange relations, and the interdependence they imply, offer a reasonably secure and productive way to mediate among all those beings. Lest I appear to stereotype Balinese as happy and cooperative good citizens, I hasten to add that disputes and bitterness place strain on these relations in Balinese communities just as they do elsewhere. Human relationships are particularly liable to end in disappointment, but the gods and spirits are not altogether dependable parties to exchange either. Nevertheless, faith in the possibility of fruitful exchange still stands, and I think that faith informs the course of "Sapu Lègèr" and the penglukatan.

Experience of Javanese social and religious life offers fewer occasions on which to develop that assurance. Life passage rituals in Java do bring about large-scale labor exchanges, and neighborhood ritual gatherings (slametan) model a certain degree of local solidarity and interdependence. Yet the kind of generalized exchange of goods and services Balinese accomplish in sekaa seems close to unimaginable in Java outside the circumstances of life crisis rituals. ${ }^{20}$

Religious emphases on autonomy and exchange. The differing religious traditions in Java and Bali may or may not offer any explanation as to why the two societies have come to differ so profoundly with respect to the extent and viability of exchange relations and the validation of interdependence. As Clifford Geertz has cautioned, there is no reason to assume that Bali

\footnotetext{
${ }^{18}$ Louis Dumont, Homo Hierarchicus, tr. M. Sainsbury, L. Dumont, and B. Gulati (Chicago: University of Chicago Press, 1980).

${ }^{19}$ Boon, Anthropological Romance.

${ }^{20}$ See on this point Ward Keeler, "Musical Encounter in Java and Bali" Indonesia 19 (April 1975): 75-119.
} 
constitutes a model of what Java would look like had Islam never arrived on its shores. ${ }^{21}$ Yet the contrasts between Muslim Javanese religious practices and Hindu Balinese ones offer telling exemplifications of the difference.

Islam in Java, particularly reformist variants of the tradition, sets itself up in explicit opposition to the kinds of exchanges among humans and spirits-ancestral, territorial, etc.- that form the core of Balinese religious practice. Islam enjoins submission, after all, not exchange. To suggest that God is susceptible to suasion, in the form of offerings, would be out of keeping with impressions of his absolute power. To suggest, furthermore, that people should concern themselves with beings other than God, whether the spirits of the ancestors of a village or the goddess of rice or whoever, is to undercut Islam's insistence on the sole and absolute authority of God. One does not negotiate any deals with God, and one should studiously avoid dealings with everything else.

Reformist Islam in Java is skeptical not only of offerings but also of ascetic exercises, looking upon such practices as remnants of Javanese heterodox procedures without sanction in written Muslim sources. Yet my impression is that fasting for forty days at Ramadan, for example, instead of the requisite Muslim thirty, which is a widespread Javanese variation on Muslim obligations and one that brings these obligations into harmony with traditional Javanese (kejawèn) patterns, arouses less censure than going to the cemetery to pray to, or (in a slightly reconstructed idiom) for, the spirits of one's ancestors in the Muslim month of Ruwah. Ascetic exercises smack of mystical beliefs but not idolatry, a more heinous fault, I believe, in the eyes of strict Javanese Muslims.

Aside from attitudes toward the value of exchange relations with supernatural beings, Javanese Islam and Balinese Hinduism differ with regard to the organizational ramifications of their practices. Stephen Lansing has described the way temple networks provide Balinese communities with a kind of organizational musculature that is both flexible and effective. ${ }^{22}$ Javanese Islam does some of the same, when it redistributes wealth through the annual tithe, when it occasions other community events, or when members of a community join together to build a prayer hall (as people did in the hamlet outside Salatiga where I lived in 1986/87). But none of these activities are on the scale of the efforts of Balinese temple organizations. Overall, Javanese religious practice tends to be much less congregational than Balinese, however strangely that adjective may ring in the context of Bali, and Javanese Islam does little to counter the impression that religious duty lies with the individual-who is responsible for the basic religious practices of Islam-rather than in networks of exchange.

Sexuality and marriage. If writing contrasts with offerings as autonomy contrasts with exchange, as I have tried to show above, then the crucial ritual gesture in Java, the reading of the serat pengruwatan, implies the imposition of authority rather than a negotiation among parties to an exchange, such as the penglukatan establishes. That contrast makes sense of the difference in the ritual procedures that win the most prominence in the two traditions, and it fits in with tendencies in Javanese and Balinese religious and social relations more generally. Another part of the stories, the beginning, points to some of the same contrasts, but this time in the idiom of marriage and sexuality.

Direct links between the story of "Lady Uma and the Cowherd," on the one hand, and the origins of Kala, on the other, are relatively rare in Bali, although the second version of

21 Clifford Geertz, Negara: the Theatre State in Nineteenth-Century Bali (Princeton: Princeton University Press, 1980), p. 7

22 Stephen Lansing, The Three Worlds of Bali (New York: Praeger, 1983). 
the story about Lady Uma's indiscretion that I have summarized above does make the connection. Nonetheless, several Balinese variants tie the Lady Uma story to Kala's pursuit of Kumara, clearly cognate with the rest of "Murwakala," and I think it reasonable to consider the beginning of each story in light of the other, since both treat of the sexual relationship between Guru and Uma.

Boon sees represented in the Balinese story the three types of Balinese marriage, as exemplified in Lady Uma's "three vaginas," that is, her vagina in its natural place, her vagina as moved to her thigh, and the split in her toe. ${ }^{23} \mathrm{I}$ find that reading compelling, but I would also note the fourth option that the Javanese version provides: leaving Lady Uma's vagina alone. Whereas "Lady Uma and the Cowherd" entertains the possibilities of bilateral generation by male and female in varying degrees of status symmetry, "Murwakala" entertains the possibility of unilateral generation by males. The whole encounter with the cowherd in the Balinese story is framed in terms of proper and improper exchanges, since Lady Uma's difficulties stem from her failure to win the sought-after milk by means of a normal exchange of valued goods. Exchange relations between male and female seem to motivate the Balinese story, whereas in Java the story starts from the premise of those relations' abrogation.

From the outset, then, the stories diverge in the degree to which issues of exchange and interdependence are put into question. In "Murwakala," the radical possibility of unilateral generation at the story's outset corresponds, in its resolution, to the radical assertion of power in writing, which is a unilateral use of language. So Javanese have molded the story in such a way as to examine the possibilities of pursuing a cultural emphasis on autonomy to a logical, and even physiological, extreme. The problem that motivates the narrative is how to assure the efficacious exercise of authority over a recalcitrant, although ultimately vanquished, subordinate. In "Lady Uma and the Cowherd," and in "Sapu Lègèr," Balinese have considered versions, and perversions, of exchange, but they never entertain the notion that exchange could be thrown over in favor of its denial through asceticism, unilateral generation, and the exercise of authority in magic writing. Instead, the story tends toward finding an appropriate and adequate form of exchange, one that will place relations between Kala and human beings in a regularized and reliable form.

The fate of stories. The contrast between Java's reliance upon the detonation of power through reading magical writing and Bali's reliance upon exchanging offerings may help to explain one other, critical contrast between the Javanese story, on the one hand, and the Balinese ones, on the other: their differing fates in performance practice in Java and Bali today. In the past, "Murwakala" and "Sapu Lègèr" were always chosen as the stories (lakon) in the shadow play put on in association with the corresponding ritual. This remains the case in Java: I have never heard of a shadow play given as a ruwatan that did not use some version of "Murwakala." In Bali, however, this is no longer true: I have never encountered a penglukatan in Bali that used any version of "Sapu Lègèr." Balinese dalang told me that they substituted some new story about the Pandawa and Kurawa whenever they performed a penglukatan because audiences preferred stories in which those characters appeared. The story, these dalang said, doesn't really matter. The important thing is that one prepare all the proper offerings and proceed with the necessary ritual gestures after the shadow play ends.

The situation is counterintuitive. Javanese, who no longer pray to the gods that figure in "Murwakala," retain the story, while Balinese, who do pray to (or at least interact in some

23 Boon, Tribes, pp. 181-88. 
manner with) those gods, put the stories about them aside. But the differing ontological status of the gods in the two societies may explain the differing means of their propitiation. Javanese see the reading of the magic writing as the truly effective act. The whole justification for that reading depends on the story of "Murwakala": it provides a context for an action that has no clear parallel elsewhere in Javanese culture. People that are in need of having a ruwatan performed are said to be at risk of being "eaten by Kala." Javanese often comment that they really have no idea what it means to talk about Kala, or of being eaten by him. Such people go on to say that it's a good idea to hold a ruwatan anyway, though, just to be sure. In Bali, giving banten to Batara Kala is only one of countless such acts of offering and so stands in no need of justification with reference to any particular story. It is one exchange among many that Balinese enter into with spirits. The story that provides the exchange with a "charter" or a context hardly seems to matter. The story may be disposable in Bali because the actions-of making offerings and carrying out ritual procedures-are so ordinary as to need no special rationale. ${ }^{24}$

\section{Convergences}

I have tried to illuminate differences between the stories of "Murwakala," on the one hand, and "Sapu Lègèr" and "Lady Uma and the Cowherd," on the other, by reference to more general differences in Javanese and Balinese culture. But the very fact that these stories are recognizably cognate with one another points to another important issue: in what respects do they repeat, or at least echo, each other, and why? If the stories change, and I wish to claim that they change for accountable reasons, then I must also account for instances in which they have not changed. Or, to consider an alternative perspective on their history, if stories in the two societies have come to resemble each other, I must account for why that convergence has taken place.

The most important such consistencies strike me as the following, arranged by the order in which they appear in the narratives: 1) in both "Murwakala" and "Sapu Lègèr," Kala threatens to devour his parents as they ride on the bull Andhini at noon, and is cheated out of making them his prey only by Guru's ruse of asking him a riddle; 2 ) in both

"Murwakala" and "Sapu Lègèr," Kala pursues his victim through villages, but he is stymied at many turns and curses anyone who would repeat whatever behavior, such as leaving off part of the roof of a house under construction, that has made it possible for his prey to escape; and 3) the stories all depict shadow plays as the means to their final resolution.

All of these consistent elements seem to me susceptible of analysis as unusual discursive forms, both as they occur in the stories and as they affect their telling. That is, each of the three incidents hinges on a particular, unusual use of language. I believe it is the nature of those discursive forms that explains particular segments' retention through a number of variants, despite whatever shifts in plot and dramatis personae occur as the stories develop in one society or the other.

\section{Kala's curses}

Perhaps this point is clearest with regard to Kala's series of curses, so I will take it out of order and discuss it first. The curses Kala makes in his pursuit of a victim constitute a segment that is consistent in the stories, even as the identity of the victim and the nature of the

24 A complete analysis of the ruwatan and the penglukatan would require examining the circumstances in which actual performances occur, an analysis I hope to make in future. 
accursed behaviors change. The repetitive structure to which the segment lends itself in the telling probably encouraged its retention in many variants. Parallelism at the level of what events are narrated and parallelism at the level of the way these events are narrated both act to strengthen the segment's cohesiveness, endowing it with a resilience other, less clearly structured incidents lack. Certainly in the performances of "Murwakala" I saw, the series, consisting of a pursuit, Kala's frustration and irritation, followed by his pronouncement of a curse, was always repeated in parallel form, giving the segment an integrity of its own.

Yet another reason that the sequence should reappear so often is that curses are a powerful and specific discursive form, and this endows them with great import in societies in which the power of language is a central concern. I have mentioned that people in Java are fascinated with the capacity of some forms of language to release power in the world, and the same is true in Bali. Arabic in Java and Sanskrit in Bali are deemed innately potent forms of language. That they are unintelligible to most people only confirms impressions of their power. Vows and magic formulas may consist of more accessible language, but they are also thought efficacious, and people pronounce vows and seek out mystically operational formulas in both societies. As for curses, belief in the efficacy of language gives them great power in both Java and Bali, ${ }^{25}$ and this must make an incident in which Kala curses missteps in everyday practice particularly impressive a part of any story.

\section{Riddles}

The incident of the riddle is also ubiquitous in "Murwakala" and "Sapu Lègèr," and its status as a set-piece probably also depends on its distinctive discursive form. The riddle that Guru puts to Kala is not identical in all versions of the myth that $I$ have collected, but it is similar in most, as it is in most of the ones Hooykaas collects in Kama and Kala. ${ }^{26}$ The most common version is exemplified in the "Kidung Sapu Lègèr" (the second version summarized above), in which Bathara Guru asks the following question of Kala:

"There are eight feet, there are four arms,

"there are three eyes, there are two horns,

"one female sex organ, two male,

"one tail-what is this?"27

The solution to the riddle is that the words describe Guru and Uma astride Guru's mount, the bull Andhini, as Kala confronts them. In most versions, Kala is unable to guess the answer, but even if he is able to do so, he still loses the right to devour his father, because in the course of the encounter the moment of noon passes by. Guru claims-and Kala accepts the claim-that this means that Kala no longer has the right to eat them.

Boon, in line with his analysis of "Lady Uma and the Cowherd," in which he sees a representation of divine-incestuous marriage, "ordinary" human marriage, and demoniccapture marriage, suggests that the riddle concerns the "conjoining of all marriage aspects, particularly the demonic-sexual." 28 Once again, I accept this reading, but I would focus

25 On Bali, see Unni Wikan, Managing Turbulent Hearts (Chicago: University of Chicago Press, 1990), p. 314, n. 1; on Java, see Ward Keeler, Javanese Shadow Plays, Javanese Selves (Princeton: Princeton University Press, 1987), pp. 124-34.

26 Hooykaas, Kama and Kala, pp. 167, 237, 257.

27 Ibid., p. 257.

28 Boon, Tribes, p. 188. 
attention as well on the pertinence to this particular riddle of the nature of riddles themselves.

Lévi-Strauss comments that a riddle sets out elements that are destined to remain apart, "a question to which one postulates that there is no answer." 29 He sees in the solving of a riddle, in both the Oedipus myth and in a North American Indian myth, a logical analogy to incest, since in both stories elements intended never to meet-consanguines with one another, or an answer with a question-are conjoined. In line with Lévi-Strauss's suggestion, the riddle in "Murwakala" and "Sapu Lègèr" prevents the "meeting" of figures, Guru, Uma, and Kala, who are destined to remain apart.

The improper conjunction that threatens is both parricidal and incestuous, as Kala threatens to eat both of his parents. So in the incident of the riddle inhere not just the three possible marriage relations, as Boon sets out, but further, relations that suggest other, impossible conjoinings: of Kala and his father through ingestion, and Kala and his mother, by ingestion/incest. Indeed, in many versions of "Murwakala" Uma is cursed by Guru to take on the form of an ogress, Durga, and becomes Kala's wife, a relationship also posited in Bali. Here, in the union of Kala and Durga, Boon's divine-incestuous and demonic dimensions combine, much as Kala-the fruit of either failed or improper intercourse-combines the status of god and demon in himself. But the conjunction of Kala and Uma that the riddle prevents becomes possible only once Uma has been cursed to take on the form of an ogress, so that the hierarchical distinction between divine and demonic is still respected, even when Kala and Durga come to form a kind of divinely demonic couple.

At the same time, the riddle exemplifies a major theme in all these stories, which is the mediation of relations by means of hierarchical distinctions and social and spatial disjunction. "Murwakala" stresses the vertical, hierarchical differences between generations in emphasizing Kala's relations with Bathara Guru. "Lady Uma and the Cowherd" and "Sapu Lègèr" emphasize the less absolute distinctions between spouses and between brothers, along with the generational distinctions between Kala and his father. In all these relations, however, as in the relations between Kala and the people at risk from his attack, the resolution is a disjunction that lets them all go their own ways. I will return to this point below, when I discuss the role of wayang in all three stories. For the moment, I point to the homology between a riddle-as per Lévi-Strauss, a question that admits of no answer and so posits a permanent disjunction-and the theme of disjunction running through all these stories.

In disjunction lies another resemblance, germane to "Murwakala": between riddles and writing. Their similiarity lies in the inability of the addressee or recipient to respond, to the person who writes, in the one case, or to the person who poses a riddle, in the other. This makes the language of riddles, like that of writing, powerful, well-suited both to the demonstration of authority and to the minimalization of exchange. Indeed, in setting the terms for the riddle, Guru sets up a perverse form of exchange. The deal he makes with Kala is such as to deny Kala what is rightfully his, according to a boon Guru himself granted to Kala earlier in the story. So Guru uses the riddle as a way to renege on an earlier obligation. A riddle, ostensibly inviting a response but intended to prevent it, is a paradoxical form of language, and it is used here, perversely, to take back what Guru had earlier given.

${ }^{29}$ Claude Lévi-Strauss, "The Scope of Anthropology," tr. Sherry Ortner Paul and Robert Paul (London: Jonathan Cape, 1967), p. 37 (emphasis in the original). 
The semantic relations, as demonstrated by Boon, between the contents of the particular riddle that appears most often in Java and Bali, and larger themes in the stories, are seconded by a discursive form that has increased the likelihood of this segment of the story reappearing in a great many renderings. Indeed, I have several variants of both "Murwakala" and "Sapu Lègèr" in which the contents of the riddles differ to one degree or another, but only in two variants, both Balinese, is the incident of the riddle omitted. This suggests to me that the discursive form of the riddle is even more powerful a reason for its retention than the pertinence to the stories of the most commonly encountered version of the riddle, the one that concerns the appearance of Guru and Uma on Andhini. The discursive form seems more salient than any particular semantic content.

\section{Shadow plays and mediated relationships}

The third incident that recurs in the stories is the shadow play that captivates Kala and enables the dalang to neutralize the threat he poses to his victims. In Java, the representation of a shadow play in a shadow play is unique, to my knowledge, to these ritual performances, and I believe there is only one other story in Bali that includes such a shadow play within the shadow play. ${ }^{30}$ Particularly in Java, where the sponsors of the ritual, the child or children being rid of their vulnerability to Kala's threat, and the village where the ruwatan is taking place, are all represented on the screen, the mirror effect of illusion and reality, the enmeshing of the everyday and the world of gods and spirits, is extraordinary.

Why should these stories, in these ritual contexts, consistently include the representation of a shadow play? I think the answer lies in a certain resonance between the nature of the ritual purpose and the circumstances of a performance, and here the notion of disjunction is once again crucial. But the problem raises the larger question of why performances of many sorts figure so prominently in these societies.

In earlier work on Javanese shadow plays, I have suggested that the nature of the medium itself suggests the mediation of relations between sponsors, performers, and spectators in ways evocative of Javanese notions of power, its proper exercise, and its influence. ${ }^{31}$ The relationship between powerful agents and people subject to that power is conceived of ideally in Java as a beneficent, non-coercive one, in which the source of power is dissembled while its good effects are enjoyed. A shadow play provides an apt image for such a relationship because the dalang is thought of as powerful and his power allencompassing, yet his presence is dissembled behind the screen and in the multiplicity of voices with which he speaks. Members of the audience, meanwhile, are in no way constrained to attend the performance. They are drawn by the attractive power of the performance itself and are free to leave when they wish. If they are inclined to stay, it is only because the dalang's potency is such as to persuade rather than oblige them to do so. Furthermore, the relations between the sponsors of the performance, who have brought the dalang in to perform, and their guests, are mediated through the dalang, who becomes the obvious, though hidden, agent of the sponsors' actual, if reticent, authority.

In the stories we are considering here, reordering relationships is precisely what a performance of a shadow play must accomplish. At ritual's end, the primary relationships are mediated properly, whereas previously they were in one way or another out of balance. Hierarchical distinctions had become effaced and/or relationships become exaggerated in

30 This is one in which Sadewa (one of the five Pandhawa) restores Durga to her original form in what I assume is simply a variant of the story, the last one summarized above, that has Iswara perform this task.

31 Keeler, Shadow Plays. 
the direction of inordinate distance or inordinate closeness. In "Murwakala," Guru oscillates between denying any responsibility for Kala and indulging him to such an extreme as to threaten the extinction of everyone. In "Sapu Lègèr," Guru's indulgence of Kala threatens Kumara, who shares his oton and therefore falls into the category of people whom Guru has granted to Kala as his rightful prey. As for "Lady Uma and the Cowherd," Lady Uma's sexual intimacy, however contorted, with a cowherd leads to her disgrace and to the eventual fate of being cursed to become an ogress. Perhaps the clearest image of relationships in need of modification occurs in "Murwakala," when the immediate reason for a shadow play's performance is a newly wed woman's request that it be put on to save the marriage she has no taste for but which her father insists she cannot undo.

Shadow plays set these relations right. The proper relationships of superiority and subordination between fathers and children, among brothers, between puppeteer and Kala, and between puppeteer and anak ruwatan, all are established in good measure in the course of the shadow plays, both the actual one we observe and the one represented within that play. In each case, the relationship at the end implies a respectful distance. In both "Murwakala" and "Sapu Lègèr," Guru's relations with Kala are no longer marked by the former's wild shifts between indulgence and neglect, nor the latter's parricidal intentions. Instead, they are transformed to become the respectful relations Kala enters into with the dalang, whom he must "recognize as his father" and see as "older," that is, of greater status, a point proven by the dalang's ability to recount Kala's origins. In a follow-up to "Lady Uma and the Cowherd," three gods take on the disguise of puppeteer and musicians in order to urge Guru and Uma to return to their true form and place in heaven rather than remain as ogres on earth.

Mediated relations as a cultural ideal. All of these relations imply a certain distance, a disjunction among the parties involved, and indeed their uninvolvement with each other. This situation describes one culturally validated model of human relationships, shared I think by many Javanese and Balinese (although perhaps more emphasized by Javanese than Balinese), a model that idealizes a measured, fairly restrained, degree of interpersonal involvement and fits those relations into hierarchical structures.

I should stress that this set of relationships constitutes a model: I don't think that it really describes people's relations as they are experienced. Nor do I think it is the only model available to people in their interaction with others. Javanese and Balinese enter into a full range of emotional relationships, and are given, like all the rest of us, to the vagaries of deep attachments and sorrowful estrangements, as well as more modulated relations of mild friendship, competition, indifference, and all the rest. (Unni Wikan's work on Balinese affective experience should correct any misimpression that Balinese are emotional cutouts. ${ }^{32}$ ) But the fact that the passions flourish in Java and Bali does not rule out the possibility that many people in those societies approach affective experience with a caution Westerners do not always share. In Indonesia, as in the West, of course, attitudes vary according to individual temperament. Yet there is a sense in Java and Bali that attachments should be held in check, and in any case restrained from undercutting hierarchical distinctions. This view is prominent in both Javanese and Balinese notions about their social relations, and it figures in many people's comments about-and actual handling of-their own affective experience. It receives greater stress among men than among women, and among higher

32 Wikan, Managing Turbulent Hearts. 
status people than among lower status ones. Yet it is espoused sufficiently widely as a basic orientation to social life as to affect many people's handling of their relations with others.

The space between people must be managed carefully, I am suggesting, so as to assure the maintenance both of an even tenor in relationships and of hierarchical distinctions as the organizing principle of those relations. This balance describes what I would label properly mediated relations, ones in which a sufficient distance is maintained between people to permit them to interact without stress. Once again, this notion is an idealized one, by no means always attained. Any two individuals may disagree on what the proper distance between them is: one person may feel that his or her superior status deserves more deference than some other person proffers, or someone may feel that another person is cold and conceited for expecting greater deference and permitting less intimacy than their relations ought to imply. But the ideal of a social life in which harmony reigns, as everyone acts in accordance with his or her status and there is never occasion for distress or ill-will, is widely shared..$^{33}$

The actual definition of those hierarchical distinctions differs to some extent in Java and Bali. The criteria by which status is defined, or rather, argued about, and the understandings of what deference and intimacy consist of, differ. The array of titles in which Balinese traffic has no real counterpart in Java, and the Javanese language, with its enormous elaboration of degrees of refinement, makes it possible to communicate fine shades of relative status in every utterance in a way that the Balinese language lacks. Furthermore, status is defined differently by different segments of Javanese and Balinese society, particularly as rank and influence in a growing, national economy and state impinge on other views of what high status means. But Javanese and Balinese share a sense that physical and linguistic styles provide a constant monitor of people's understandings of their relations, and those relations always imply status considerations. It is true in both Java and Bali that there are countercurrents: some effort is made to dissemble status distinctions in certain situations, such as in Javanese ritual meals (slametan) or Balinese work groups (sekaa). Yet even there hierarchical distinctions can rarely be effaced entirely.

The pervasiveness of the model of social relations that emphasizes a certain mediated distance helps to explain the often-noted propensity among Javanese and Balinese to negotiate their relations with others through third parties. When such go-betweens come into play, the mediated nature of social relations is striking: an intermediary makes it possible to negotiate relations at a sometimes surprising distance. Marriages are the most obvious example, but everything from business deals to ritual celebrations to curing may be organized and modified through the offices of such third parties.

The dalang as mediator. A puppeteer is just such a third party. He is a peculiarly apt figure with which to represent the mediation of social relations, including their modulation from intense to more manageable forms, because he is an agent both effective and largely unseen and can therefore become a generalized image of benevolent authority. (This rendering of a puppeteer seems more evident in Java than in Bali, but many passages in various texts of the Darma Pawayangan cited by Hooykaas support the image of a protective, benevolent

33 Unni Wikan suggests (ibid.) that the ultimate rationale for the Balinese emphasis on grace and good cheerwhich I would link to a desire to maintain an even, somewhat distanced relationship with all but one's closest kin and friends-lies in fears of black magic. I think she exaggerates those fears somewhat, but more to the point, I think she takes as cause fears that are instead simply elements in a larger set of attitudes toward interaction, attitudes that disvalue intense investments or a great degree of interdependence. 
agent. ${ }^{34}$ ) Within the stories, the links between people become ordered in relation to the dalang. He can stand in, as a kind of transitional place marker, for other figures, such as Guru vis-à-vis Kala, or the village headman vis-à-vis his daughter, the reluctant bride, in "Murwakala," and so he can graduate the relations between those paternal figures and their progeny. He does the same, in "Sapu Lègèr," when he intercedes between Kala and Kumara, taking the latter's part much as Guru himself does earlier in the story. The very fact that the dalang replicates these fathers means that the true fathers have been displaced, and the bonds between them and their children become to a considerable degree diminished. In each case, the dalang is the third party necessary to institute an appropriate distance that people have failed to arrive at on their own. One may be put in mind here of a therapist in the West, upon whom difficult relationships are projected, sometimes with the purpose of reducing their intensity. But in Java and Bali the patient is relieved of the responsibility of doing all the work.

It is worth noting that the words used in both Javanese and Balinese to describe these rituals, ruwat and lukat, suggest release, and what the rituals achieve is the release of the anak ruwatan from the threat Kala poses to them. That means release from danger, a danger that arises because someone is (in Javanese) sukerta or (in Balinese) leteh, both terms meaning something like "ritually compromised" or "defiled." But I think release suggests, in the broader context of all the relationships the ritual establishes and then largely sunders, release from obligation, from responsibility, from involvement and undue interdependence. In Bali, the responsibility to give offerings remains more prominent than in Java, but even giving offerings is intended to keep Kala away, and so to establish a disjunction that the ritual takes as its goal.

The person on whose behalf the ritual is held seeks to be released from Kala's threats, just as the baby born during the performance represented in "Murwakala" is released from Kala's grip. Understanding that release as release from inordinate or unmediated involvement with others helps one to understand the place of shadow plays in all these stories. The relationship between puppeteer and Kala, as I have said, mediates the relations between Guru and Kala, and in the process, mediates those between Kala and his intended victims, namely, those on whose behalf the ruwatan or penglukatan is performed. The connection between the dalang and Kala is conducive to such a representation of other relationships, because it is in itself a distanced, mediate link, one in which Kala enters into the role of spectator relative to the world depicted by the dalang on the screen. This relationship evolves into another one, as the performance Kala watches ends and the story continues. But the end result is similar in principle to the distanced relationship-mediated by the performancebetween Kala and the dalang at the outset. That is, the relationship that obtains between the dalang and Kala at the conclusion of the ruwatan or penglukatan puts them in contact with each other, but across a considerable distance: in Java and Bali alike, Kala accepts certain offerings, but on the condition that he leave the scene, while the dalang, by the same token, enjoys the status of superior party but is not responsible for his subordinate, Kala. That endpoint is both prefigured in and initiated by the earlier relationship obtaining between them, which is that of performer and spectator. Neutralizing Kala's threat to humans depends on his first falling prey to the power of a performance.

Performances as interaction. Perhaps the reason performances are so important in efforts to restrain Kala and in protecting the anak ruwatan lies precisely in the peculiar-but sug-

${ }^{34}$ Hooykaas, Kama and Kala. 
gestive-nature of the relationships established by performances. In the image of Kala captivated by the dalang's performance (in Java) and/or the offerings (in Bali), one sees the first sign of his submission, and the first step in exerting control over him on behalf of the ritual's sponsors. Yet the aptness of the image of Kala observing a shadow play does not explain why this motif should prove so widespread. Once again, I think the prominence of this motif stems from the properties of performances as particular discursive forms, quite distinct from other forms of language use and interaction in general.

I have said that the curses and the riddle which occur in earlier parts of the stories may be ubiquitous because they constitute unusual uses of language. Both are predicated on using language not in ordinary exchange but rather in unleashing power and the prevention thereby of some action by Kala. In "Murwakala," the same may be said of writing. Performances, especially shadow plays, are also characterized by unusual discursive traits that set them apart from ordinary speech, and they, too, impose severe and unusual restraints on the actions of their observers.

A performance-I am speaking here of a genre, such as shadow plays, that makes a clear demarcation between a performance and its audience-constitutes a dramatic demonstration, an enactment, of language and interaction. But as a demonstration, it is bracketed apart from everyday practice. It is, as Victor Turner was fond of putting it, action "in the subjunctive mode." Shadow plays play on the paradox of a multiplicity of voices issuing from only one person, and so of interaction among characters who are at the same time only one. This makes them especially conducive to representation of a performer's, a puppeteer's, power. But all performances are situated ambiguously and intriguingly on a peculiar middle ground between social interaction and its converse, the absence of all social connections.

A performance, like writing, curses, and riddles, does not admit of a response in any direct sense. Spectators do not enter into the exchange of speech that takes place in a performance, they only observe it. Kala points up the rule when he breaks it: his interruption of the dalang brings rebukes down on his head. However, spectators can respond in more oblique ways, attending to, being moved or interested by, laughing at, or ignoring a performance. Even if they choose to attend, to attend to, and to respond to what happens in a performance, they do so in an attenuated form. So spectators enter into a very unusual relationship with the performance they observe, and with the performers enacting the performance.

The role of spectator does, however, imply a number of things about spectators: 1) their superior knowledge, since they are aware of more than any one character is aware; 2) their autonomy, since they are able to attend to or ignore or leave the performance as they please; 3) their emotional and physical safety, since they are exempt from the obligation to act; and 4) their impotence, since they are excluded from the action and are in fact largely passive. The paradoxical nature of these relations makes them analogous to, although in a highly exaggerated form, the mediated relations between Kala, the dalang, and other figures in the stories at the end of the ruwatan and penglukatan. There is a kind of tenuous, largely nonbinding, but nonetheless real connection among these figures at the performance's end, and that connection resonates with the bonds that join, but do not really bind, spectators to a performance. So beyond the particular ritual purposes of the ruwatan and penglukatan, the relations between performance and audience resonate with an idealized, indeed impossible, version of human relationships, in which vulnerability, obligation, and even commitment, have been largely effaced.

It is worth stressing in this regard an obvious fact about performances: that few occasions in life apart from sleep limit the extent of our physical activity as much as 
performances do. This is particularly true in Java and Bali, where solitary reading is rare. Granted, relatively few spectators of Indonesian arts sit silently in individual seats in darkened halls like Western audiences of bourgeois art forms. Yet they are gathered together and held attentive to a performance, if it is to their taste, in such a way that they move much less and say much less than would be true under virtually any other circumstances. Attending a performance enables people to fulfill a desire to opt out of social interaction, to be released from the obligation to interact in any but minimal ways.

There is one more relationship occasioned by performances that is a kind of complement to the distanced one between spectator and performance, namely, the relations among members of an audience. In this case, relations obviate speech almost entirely. In responding spontaneously but collectively to a performance, whether in sadness, laughter, or simply attentiveness, members of an audience enter into relations with each other that once again represent an attenuated form of interaction, but one that plays a rather different set of variations on mediated bonds. Closer to Durkheim's collective effervescence than to any other situation in Balinese and Javanese life, the peculiar camaraderie that obtains within an audience is also the closest people come to what Clifford Geertz describes as a Balinese tendency to "depict virtually everyone... as stereotyped contemporaries, abstract and anonymous fellowmen." 35 An exaggerated claim if applied to people's everyday relations, the description is apt when applied to members of an audience, who are indeed relatively abstract and anonymous for each other as long as their attention is fixed on the performance. Yet even then, the description needs to be amended to note that members of an audience enjoy a kind of anonymous intimacy. Physical closeness in Java and Bali varies according to the age and status of spectators. Young people of either gender among themselves, most women, or adults of either gender with their children, are usually free to touch and lean against each other at will, while grown males, and adult men and women with members of the opposite sex, must usually show more restraint. Yet whether such physical proximity is permissible or not, at a performance a sense of emotional coparticipation or coordination, the experience of shared (and shifting) affects, suggests a kind of immediate communication or involvement among all those present-a feeling all the more palpable when a performance wins enthusiastic appreciation. This is another diminished and therefore safe but alluring form of interaction, one that the pervasiveness of performance genres in Java and Bali suggests is particularly satisfying to people in those societies. Perhaps the fact that status considerations matter so much less in these circumstances than in face-to-face encounter accounts for much of these performances' allure.

In sum, the motif of the shadow play appears in both "Murwakala" and "Sapu Lègèr" as the mechanism of Kala's subjugation because it provides an effective image of subjection to a subtle but real power, that of the dalang and the performance he gives. At the same time, that relationship describes the relations that obtain between the spectators of the actual performance and the dalang. In either case, the particular characteristics of performances as unusual discursive forms make them apt exemplars of an idealized relationship in Java and Bali, because they suggest appropriately distanced relations between beneficent superiors and dependent-but almost autonomous-subordinates. Complementary to those relations, meanwhile, are the warm but largely anonymous, status-free relations with other members of the audience that obtain as long as the performance continues. Perhaps this satisfaction of contrary but still complementary inclinations helps to explain the great popularity of per-

35 Clifford Geertz, "Person, Time, and Conduct in Bali," in The Interpretation of Cultures (New York: Basic Books), p. 389. 
forming arts in Java and Bali, and even some of our own fascination with these dazzling art forms.

I have approached certain stories and rituals in Java and Bali in a deliberately eclectic manner. I am not unmindful of the risks of sociological determinism, formalism, overgeneralization, and reductionism such eclecticism entails. But the alternative, treating stories and rituals as irreducible as well as incomparable expressive forms, seems to me an impoverishment still more desolating in its consequences than a reductive treatment of their significance implies. My point is that in looking at the relations among stories, rituals, and people in particular societies, and then comparing those relations in related societies, we can begin to appreciate the resonances, dissonances, and particularities of the societies we study. 
